Article

\title{
Synthesis, Crystal Structures, and Anti-Liver Cancer Activity Studies on Three Similar Coordination Polymers
}

\author{
Bao-Hua Song ${ }^{1}$, Xing Ding ${ }^{2}$, Chen $\mathrm{Li}^{1}$ and Gui-Feng An ${ }^{1,3, *}$ \\ 1 Medical College, Inner Mongolia University for Nationalities, Tongliao 028000, China; \\ sbhlsh@163.com (B.-H.S.); lichen199410@gmail.com (C.L.) \\ 2 Department of Neurosurgery, Shaoxing Second Hospital, Shaoxing 312000, China; dingxing0221@163.com \\ 3 Department of Gastroenterology, the First Affiliated Hospital of Inner Mongolia University for Nationalities, \\ Tongliao 028000, China \\ * Correspondence: anguifeng1224@163.com
}

Received: 22 April 2018; Accepted: 8 May 2018; Published: 10 May 2018

\begin{abstract}
By employment of a pre-designed molecular building block [(pzTp) $\left.\mathrm{Fe}(\mathrm{CN})_{3}\right]$, one cyano-bridged trinuclear complex $\left[\mathrm{MnMe}_{4} \mathrm{TACD}\right]\left[(\mathrm{pzTp}) \mathrm{Fe}(\mathrm{CN})_{3}\right]_{2}\left(\mathrm{H}_{2} \mathrm{O}\right)_{16} \mathbf{1}$, [pzTp = tetrakis(pyrazoly) borate, $\mathrm{Me}_{4} \mathrm{TACD}=1,4,7,10$-tetramethyl-1,4,7,10-tetraazacyclododecane] and two 1D chain-like coordination polymers $\left\{\left[(\mathrm{pzTp}) \mathrm{Fe}(\mathrm{CN})_{3}\right]_{2}\left[\mathrm{M}(\mathrm{Bim})_{2}\right]\left(\mathrm{H}_{2} \mathrm{O}\right)_{2}\right\}_{\mathrm{n}}[\mathrm{M}=\mathrm{Cu}(\mathrm{II})$ for 2 and $\mathrm{Mn}$ (II) for 3, Bim $=$ bis(1-imidazolyl)methane] were synthesized by making use of different nitrogen-containing organic linkers. Furthermore, in vitro cytotoxicity of compounds 1-3 was studied against four human liver cancer cells (HepG2, Bel-7402, SMMC7721, and MHCC97) via the 3-(4,5-dimethylthiazol-2-yl)-2,5-diphenyl tetrazolium (MTT) assay experiments.
\end{abstract}

Keywords: coordination compounds; X-ray; cancer cells

\section{Introduction}

Nowadays, it has been widely accepted that cancer is one of the major threat to the health of people worldwide which could cause millions of deaths every year [1]. In spite of great efforts have been devoted to the creation of therapeutic tools, chemotherapy is still the dominant treatment method. In this case, the search of effective chemotherapy drugs with low cost, high selectivity, lack of undesirable side effects, and low cytotoxicity is of high importance [2,3]. The cancer cell resistance to anticancer agents and the toxicity of modern chemotherapy make the sciences worldwide search for new drugs and cure methods for such an insidious disease [4].

Metal-organic coordination polymers have been rapidly developed in the past decades due to their fascinating structures or topologies, especially their potential use as functional materials in various key domains such as asymmetrical catalysis, energy gas storage and separation, molecular and ionic magnetism, guest-dependent luminescence, and so on [5-10]. Many efforts have been devoted to selecting suitable ligands because they play important roles in the guiding the formation of the obtained produces with targeted chemical and physical characters [11]. The organic ligands containing $\mathrm{N}$ atoms have received considerable attention for the versatile binding modes as a bridging linker between inorganic moieties $[12,13]$. In recent years, $\left[(\mathrm{pzTp}) \mathrm{Fe}(\mathrm{CN})_{3}\right]$ has been used as a pre-designed molecular building block to construct heterometallic coordination polymers, which show interesting structural diversity and outstand properties [14]. For instance, Oshio and co-workers reported a series of heterometallic coordination polymers constructed from the [(pzTp) $\mathrm{Fe}(\mathrm{CN})_{3}$ ] building blocks, which demonstrate both electric and magnetic bistability [15]. In this work, we chose $\left[(\mathrm{pzTp}) \mathrm{Fe}(\mathrm{CN})_{3}\right]$ to react with different metal ions and different N-donor organic 
ligands to afford one cyano-bridged trinuclear complex [MnMe $\mathrm{MACD}_{4}\left[(\mathrm{pzTp}) \mathrm{Fe}(\mathrm{CN})_{3}\right]_{2}\left(\mathrm{H}_{2} \mathrm{O}\right)_{16} \mathbf{1}$, (pzTp = tetrakis(pyrazoly)borate, $\mathrm{Me}_{4} \mathrm{TACD}=1,4,7,10$-tetramethyl-1,4,7,10-tetraazacyclododecane) and two $1 \mathrm{D}$ chain-like coordination polymers $\left\{\left[(\mathrm{pzTp}) \mathrm{Fe}(\mathrm{CN})_{3}\right]_{2}\left[\mathrm{M}(\mathrm{Bim})_{2}\right]\left(\mathrm{H}_{2} \mathrm{O}\right)_{2}\right\}_{n}(\mathrm{M}=\mathrm{Cu}(\mathrm{II})$ for 2 and $\mathrm{Mn}$ (II) for 3, Bim = Bis(1-imidazolyl)methane, Figure 1) with interesting structural diversity. Additionally, in vivo anticancer activity of compounds 1-3 was then evaluated.
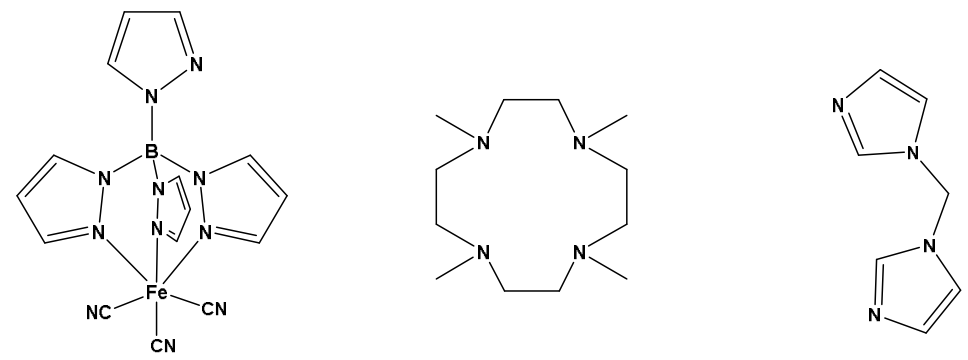

Figure 1. The chemical drawings of the $\left[(\mathrm{pzTp}) \mathrm{Fe}(\mathrm{CN})_{3}\right]$ molecular building block (left), 1,4,7,10-tetramethyl-1,4,7,10-tetraazacyclododecane (middle), and the bis(1-imidazolyl)methane (right) used in this research.

\section{Materials and Methods}

\subsection{Instruments and Chemicals}

A Rigaku D/MAX 2500V diffractometer (Rigaku Corporation, Tokyo, Japan) was used to collect the powder X-ray diffraction (PXRD) curves. An Oxford Xcalibur E diffractometer with Mo-K $\alpha$ radiation $(\lambda=0.71073)$ was employed to collect the single crystal $X$-ray diffraction data. A Perkin Elmer model 240C (PerkinElmer, Norwalk, CT, America) instrument was employed to obtain the element analyses $(\mathrm{C}, \mathrm{H}$, and $\mathrm{N})$ results. All the chemicals in this study were commercially available and used as received. $\mathrm{Bu}_{4} \mathrm{~N}\left[\mathrm{pzTpFe}(\mathrm{CN})_{3}\right], \mathrm{Me}_{4} \mathrm{TACD}$, and Bim ligands were bought from Ji'nan Heng Hua Technology Co., Ltd. (Ji Nan, China) at analytical grade. $\mathrm{Mn}\left(\mathrm{NO}_{3}\right)_{2}(\mathrm{aq}, 50 \% w / w)$ and $\mathrm{Cu}\left(\mathrm{NO}_{3}\right)_{2} \cdot 6 \mathrm{H}_{2} \mathrm{O}$ were purchased from Alfa Aesar Chemical Reagent company (Tianjin, China) at analytical grade.

\subsection{Preparation and Characterization for Compounds $\mathbf{1}-\mathbf{3}$}

A $10.0 \mathrm{~mL}$ ethanol solution containing $0.10 \mathrm{mmol}(65.5 \mathrm{mg})$ of $\mathrm{Bu}_{4} \mathrm{~N}\left[\mathrm{pzTpFe}(\mathrm{CN})_{3}\right]$ and $0.20 \mathrm{mmol}$ (45.0 mg) of $\mathrm{Me}_{4}$ TACD was added dropwise to a $10.0 \mathrm{~mL}$ aqueous solution containing $0.10 \mathrm{mmol}$ of $\mathrm{Mn}\left(\mathrm{NO}_{3}\right)_{2}(\mathrm{aq}, 50 \% \mathrm{w} / \mathrm{w})$. The as-made suspension was mixed tempestuously via stirring for $3 \mathrm{~h}$ and then filtrated to remove the solid. After filtration, slow evaporation of the filtrate in air gave black crystals after several days. Analytical calcd for compound $\mathbf{1}\left(\mathrm{C}_{42} \mathrm{H}_{90} \mathrm{~B}_{2} \mathrm{MnFe}_{2} \mathrm{~N}_{26} \mathrm{O}_{19}\right): \mathrm{H}, 6.25 ; \mathrm{C}, 34.75$; $\mathrm{N}, 25.09 \%$; found: $\mathrm{H}, 6.11 ; \mathrm{C}, 35.02 ; \mathrm{N}, 25.26 \%$.

A $10.0 \mathrm{~mL}$ methanol solution containing $0.10 \mathrm{mmol}(65.5 \mathrm{mg})$ of $\mathrm{Bu}_{4} \mathrm{~N}\left[\mathrm{pzTpFe}(\mathrm{CN})_{3}\right]$ and $0.20 \mathrm{mmol}(29.0 \mathrm{mg})$ of Bim ligand was added dropwise to a $10.0 \mathrm{~mL}$ aqueous solution containing $0.10 \mathrm{mmol}(24.0 \mathrm{mg})$ of $\mathrm{Cu}\left(\mathrm{NO}_{3}\right)_{2} \cdot 6 \mathrm{H}_{2} \mathrm{O}$. The as-made suspension was mixed tempestuously via stirring for $3 \mathrm{~h}$ and then filtrated to remove the solid. After filtration, slow evaporation of the filtrate in air gave black crystals after several days. Analytical calcd for $2\left(\mathrm{C}_{72} \mathrm{H}_{68} \mathrm{~B}_{2} \mathrm{CuFe}_{2} \mathrm{~N}_{28} \mathrm{O}_{10}\right): \mathrm{H}, 3.63 ; \mathrm{C}$, 43.25; N, 34.39; found: H 3.29, C 43.11, N 34.08 .

The synthesis process of complex 3 was similar to that of 2 , except that the equal amount of $\mathrm{Mn}\left(\mathrm{NO}_{3}\right)_{2}$ (aq, $50 \%$ w/w) was used to replace $\mathrm{Cu}\left(\mathrm{NO}_{3}\right)_{2} \cdot 6 \mathrm{H}_{2} \mathrm{O}$. Analytical calcd for 3 $\left(\mathrm{C}_{72} \mathrm{H}_{68} \mathrm{~B}_{2} \mathrm{MnFe}_{2} \mathrm{~N}_{28} \mathrm{O}_{10}\right): \mathrm{H}, 3.66 ; \mathrm{C}, 43.56$; N, 34.63; found: $\mathrm{H} 3.49, \mathrm{C} 43.42, \mathrm{~N} 34.55$.

\subsection{Crystal Structure Determination}

An Oxford Xcalibur E diffractometer with graphite monochromatized Mo K radiation $(0.71073 \AA)$ was used to collect the reflection data of $\mathbf{1}-\mathbf{3}$ at $298 \mathrm{~K}$. The direct method in the XS program was used 
to get the initial structural modes and the least-squares method in XL program was used to refine the structural models. All the $\mathrm{H}$ atoms on the organic ligands were generated geometrically, and all non-hydrogen atoms in the two structures were treated anistropically. For the highly-disordered nature of the seven water molecules in 1, they could not be figured out appropriately from the Fourier map, so the SQUEEZE manipulation in the software PLATON(version: 1.18) was used to remove their electronic contribution. The SQUEEZE calculation result reveals that each unit cell contains 1256 electrons, corresponding to 78.5 electrons $\left(7.85 \mathrm{H}_{2} \mathrm{O}\right)$ per molecular unit, which is near to the value derived from the element analyses (eight $\mathrm{H}_{2} \mathrm{O}$ per molecular unit). Table 1 shows the crystal data and the structure refinements. Pertinent crystal data and structural refinement results for compounds 1-3 were summarized in Table 1.

Table 1. The crystalline data and refinement parameter for complexes 1-3.

\begin{tabular}{cccc}
\hline & $\mathbf{1}$ & $\mathbf{2}$ & $\mathbf{3}$ \\
\hline Formula & $\mathrm{C}_{48} \mathrm{H}_{72} \mathrm{~B}_{2} \mathrm{Fe}_{2} \mathrm{MnN}_{22}$ & $\mathrm{C}_{44} \mathrm{H}_{44} \mathrm{~B}_{2} \mathrm{CuFe}_{2} \mathrm{~N}_{30} \mathrm{O}_{2}$ & $\mathrm{C}_{44} \mathrm{H}_{44} \mathrm{~B}_{2} \mathrm{Fe}_{2} \mathrm{MnN}_{30} \mathrm{O}_{2}$ \\
$M r$ & 1145.53 & 1221.95 & 1213.32 \\
$T / \mathrm{K}$ & $298(3)$ & $298(3)$ & $298(3)$ \\
Crystal system & Orthorhombic & Monoclinic & Monoclinic \\
Space group & $F d d d$ & $P 2_{1} / n$ & $P 21 / n$ \\
$a / \AA$ & $16.8839(6)$ & $8.4126(3)$ & $8.6043(11)$ \\
$b / \AA$ & $25.7793(6)$ & $16.1784(5)$ & $16.1504(19)$ \\
$c / \AA$ & $62.8204(17)$ & $19.4159(6)$ & $19.470(2)$ \\
$\alpha /^{\circ}$ & 90 & 90 & 90 \\
$\beta /^{\circ}$ & 90 & $92.007(2)$ & $92.126(9)$ \\
$\gamma /{ }^{\circ}$ & 90 & 90 & 90 \\
$V / \AA^{3}$ & $27,342.9(14)$ & $2640.93(15)$ & $2703.7(6)$ \\
$Z$ & 16 & 2 & 2 \\
$D_{\text {calc }} / \mathrm{g} \cdot \mathrm{cm}^{-3}$ & 1.113 & 1.537 & 1.4902 \\
$\mu($ Mo K $\alpha) / \mathrm{mm}^{-1}$ & 0.646 & 1.012 & 0.828 \\
$R_{\text {int }}$ & 0.0632 & 0.0920 & 0.0493 \\
$R_{1}$ & 0.0433 & 0.0570 & 0.0417 \\
$\omega R_{2}$ & 0.1303 & 0.1649 & 0.1201 \\
$\mathrm{CCDC}$ number & $1,832,283$ & $1,832,284$ & $1,832,285$ \\
\hline
\end{tabular}

\subsection{Antitumor Activity}

Four human liver cancer cell (HepG2, Bel-7402, SMMC7721, and MHCC97) lines were developed in a RPMI 1460 medium supplemented with 10\% fetal calf serum, $0.1 \mathrm{~g} / \mathrm{L}$ streptomycin and $0.1 \mathrm{~g} / \mathrm{L}$ penicillin. The above systems were incubated in a humidified incubator with air and $\mathrm{CO}_{2}(95: 5, v: v)$ at $37^{\circ} \mathrm{C}$. RPMI 1640 was used to dilute the cell to a concentration of $5 \times 10^{4}$ cells $/ \mathrm{mL}$. The 96 -well cell culture at a volume of $100 \mu \mathrm{L}$ per cell was used to seed the cells. Then the system was incubated for $24 \mathrm{~h}$ at $37^{\circ} \mathrm{C}$ in $5 \% \mathrm{CO}_{2}$. The MTT solution $(0.5 \mathrm{mg} / \mathrm{mL}, 150 \mu \mathrm{L})$ was added to each well tested and the plates were cultured for $4 \mathrm{~h}$. Afterwards, $100 \mu \mathrm{L}$ of dimethyl sulfoxide (DMSO) was transferred into each well to dissolve the samples. A microplate reader (Per-kinElmer, Waltham, MA, USA) was used to record the absorbance at a wavelength of $450 \mathrm{~nm}$, which is further used in the calculation of the cell relative viability. Each parallel experiment was carried out for at least three times to obtain the mean values.

\section{Results and Discussion}

\subsection{Molecular Structure}

An evaporation method was used in the synthesis of the single crystals of $\mathbf{1}$ in a beaker. The X-ray single-crystal investigation demonstrates that $\mathbf{1}$ locates in the orthorhombic crystal system, the Fddd space group with a large cell volume of $27,342 \AA^{3}$. The molecular unit of $\mathbf{1}$ is composed of neutral $\left[\mathrm{MnMe}_{4} \mathrm{TACD}\right]\left[(\mathrm{pzTp}) \mathrm{Fe}(\mathrm{CN})_{3}\right]_{2}$ cluster as well as the lattice water molecules. In the structure of the trcore unit, the $\left[\mathrm{Fe}^{\mathrm{III}}(\mathrm{CN})_{3}(\mathrm{pzTp})\right]^{-}$building block behaves as a monodentate linker using its one 
cyano group to connect with the $\left[\mathrm{MnMe}_{4} \mathrm{TACD}\right]$ unit, while each $\left[\mathrm{MnMe}_{4} \mathrm{TACD}\right]^{2+}$ building block is coordinated to two $\left[\mathrm{Fe}^{\mathrm{III}}(\mathrm{pzTp})(\mathrm{CN})_{3}\right]^{-}$building blocks, leading to the formation of a centrosymmetric neutral trcore $\left[\mathrm{MnMe}_{4} \mathrm{TACD}\right]\left[(\mathrm{pzTp}) \mathrm{Fe}(\mathrm{CN})_{3}\right]_{2}$ molecular structure. Within the structure of the trcore unit, there is one crystallographically independent $\mathrm{Fe}(\mathrm{III})$ ion (labeled as Fe1) and one $\mathrm{Mn}$ (II) ion (labeled as Mn1). In the $\left[\mathrm{Fe}^{\mathrm{III}}(\mathrm{pzTp})(\mathrm{CN})_{3}\right]^{-}$anion, the six-coordinated $\mathrm{Fe}(\mathrm{III})$ ion is bonded to three $\mathrm{N}$ donors from there $\mathrm{pz}$ linkers with the leaving coordinating sites completed via the $\mathrm{C}$ donors on three $\mathrm{CN}$ ions (Figure 2a). The Fe-N bond distances locate in the region of 1.990(2) to 2.013(2) $\AA$ while the Fe-C bond distances range from 1.918(3) to 1.932(3) $\AA$, respectively, which are comparable to those reported in the literature which are also formed as $\mathrm{Fe}^{\mathrm{III}}$ tricyanide metal-organic complexes. As for the $\mathrm{Mn}^{2+}$ ion in the [MnMe$\left.{ }_{4} \mathrm{TACD}\right]$ unit, it six-connects with the $\mathrm{N}$ donors on the four $\mathrm{Me}_{4} \mathrm{TACD}$ ligands and two $\mathrm{N}$ donors on two independence $\left[(\mathrm{pzTp}) \mathrm{Fe}(\mathrm{CN})_{3}\right]$ units with a N-Mn lengths ranging from 2.195(3) to 2.391(3) $\AA$. Two Fe(III) centers and one Mn(II) center were arranged in a winding array with a Fe-Mn-Fe angle of $87.5^{\circ}$ (Figure 2b). Furthermore, the adjacent trinuclear cluster are interacted with each other though the $\pi-\pi$ interaction of the pz rings to form a $1 \mathrm{D}$ chain-like supermolecular structure (Figure 2c).

a)

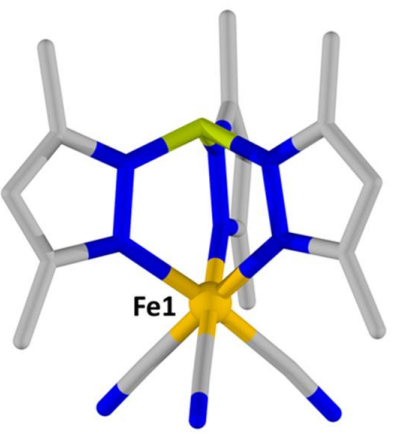

b)

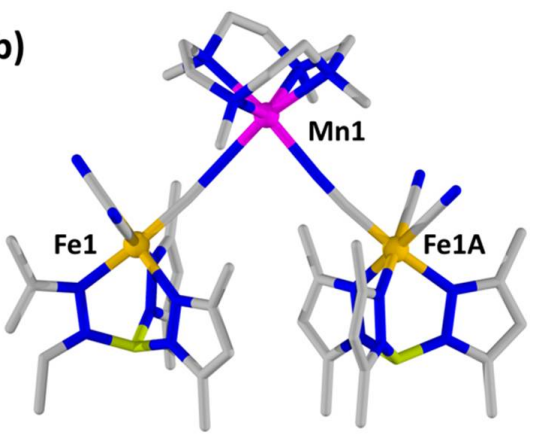

c)

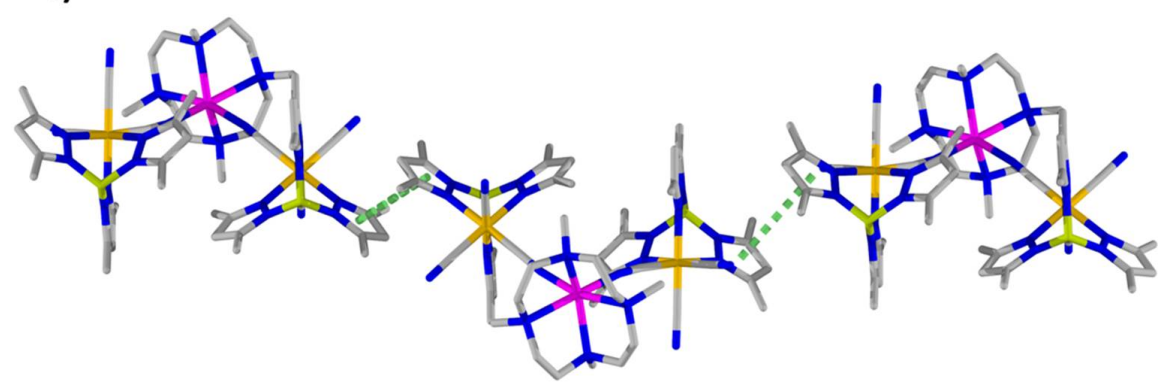

Figure 2. (a) View of the $\left[\mathrm{Fe}^{\mathrm{III}}(\mathrm{pzTp})(\mathrm{CN})_{3}\right]^{-}$anion in $1 ;(\mathbf{b})$ the molecular unit in 1 ; and (c) the $\pi-\pi$ interaction in 1.

Complexes 2 and 3 could be obtained in a moderate yield using a slow volatilization method, and their structures were fully studied by the X-ray single crystalline diffraction technology, which shows that both complexes are isomeric and possess similar 1D chain-like framework. Thus, herein we only describe the structure of complex 2 in detail. X-ray single-crystal diffraction analyses revealed that complex 2 locates in the monoclinic crystal system, $\mathrm{P} 2_{1} / \mathrm{n}$ space group and demonstrates a $1 \mathrm{D}$ chain-like structure. The crystal structure comprises of two components: one is the $\left[\mathrm{Fe}^{\mathrm{III}}(\mathrm{pzTp})(\mathrm{CN})_{3}\right]^{-}$ anion and the other is the $1 \mathrm{D} \mathrm{Cu}(\mathrm{II})$ chains that formed by the connection of the $\mathrm{Cu}$ (II) ions by the Bim ligands along the a axis. As shown in Figure $3 \mathrm{a}$, in the $\left[\mathrm{Fe}^{\mathrm{III}}(\mathrm{pzTp})(\mathrm{CN})_{3}\right]^{-}$anion, the six-coordinated $\mathrm{Fe}(\mathrm{III})$ atom is coordinated to three $\mathrm{N}$ donors from three independence pz linkers with the leaving binding sites completed via the $\mathrm{C}$ donors on the three $\mathrm{CN}$ ions. The Fe- $\mathrm{N}$ bond lengths are in the region of 1.953(3) to 1.995(3) $\AA$ and the Fe-C bond distance varies from 1.925(4) to 1.932(4) $\AA$, respectively, which are comparable to those reported in the literature, which are also formed as $\mathrm{Fe}^{\mathrm{III}}$ tricyanide 
metal-organic complexes. As for the $\mathrm{Cu}^{2+}$ ion in the 1D chain (Figure 3b), it binds with six nitrogen donors on four Bim linkers and two nitrogen donors from the $\left[\mathrm{Fe}^{\mathrm{III}}(\mathrm{pzTp})(\mathrm{CN})_{3}\right]^{-}$anion with a N-Cu distances varying from 2.243(3) to 2.270(3) $\AA$, forming a distorted octahedral geometry. Each $\mathrm{Cu}^{2+}$ ion is connected with two $\left[\mathrm{Fe}^{\mathrm{III}}(\mathrm{pzTp})(\mathrm{CN})_{3}\right]^{-}$anions though the $\mathrm{CN}$ group on the $\left[\mathrm{Fe}^{\mathrm{III}}(\mathrm{pzTp})(\mathrm{CN})_{3}\right]^{-}$anion, which is further linked with the adjacent $\mathrm{Cu}^{2+}$ ions though four Bim ligands in a double-walled model. Such connection modes results in the formation of the 1D chain-like framework of 2 . The 1D chains are further stacked in an $\mathrm{ABAB}$ fashion in the three-dimensional direction to form a 3D supermolecular network (Figure 3c). We carried out the power X-ray diffraction measurement for the three compounds, and the results are shown in Figure 4. The well match between their simulated peaks with the peaks of their prepared samples confirmed the phase purity of their prepared samples.

\section{a)}

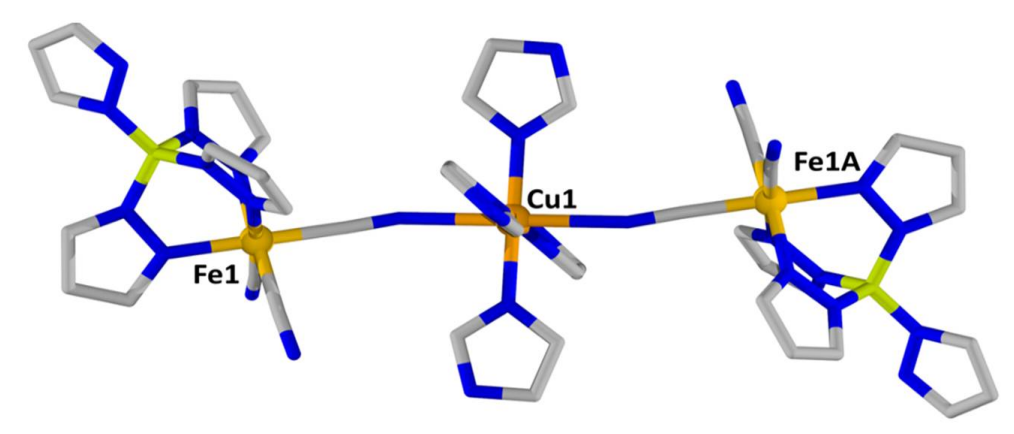

b)

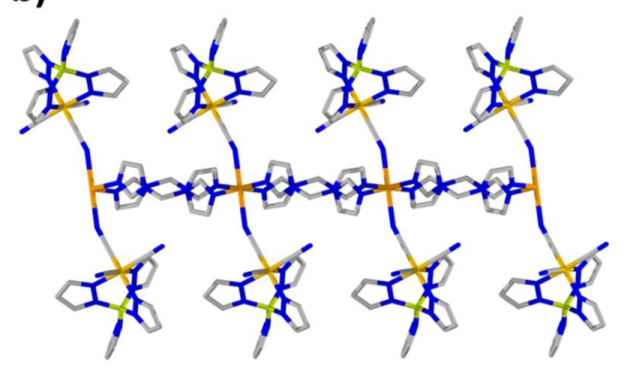

c)

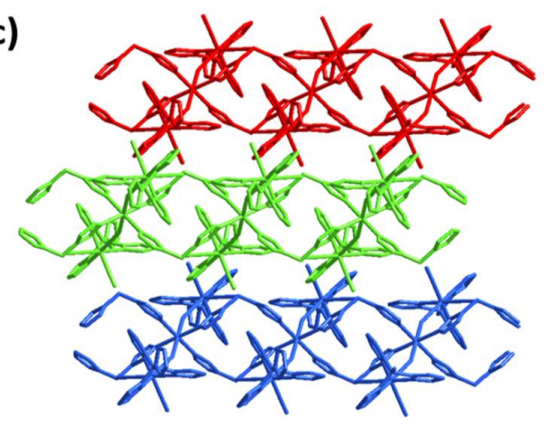

Figure 3. (a) The coordination surrounding of $\mathrm{Fe}^{3+}$ atom and $\mathrm{Cu}^{2+}$ atom in 2; (b) the one-dimensional chain-like framework of $\mathbf{2}$; and (c) the ABAB stacking mode of $\mathbf{2}$.

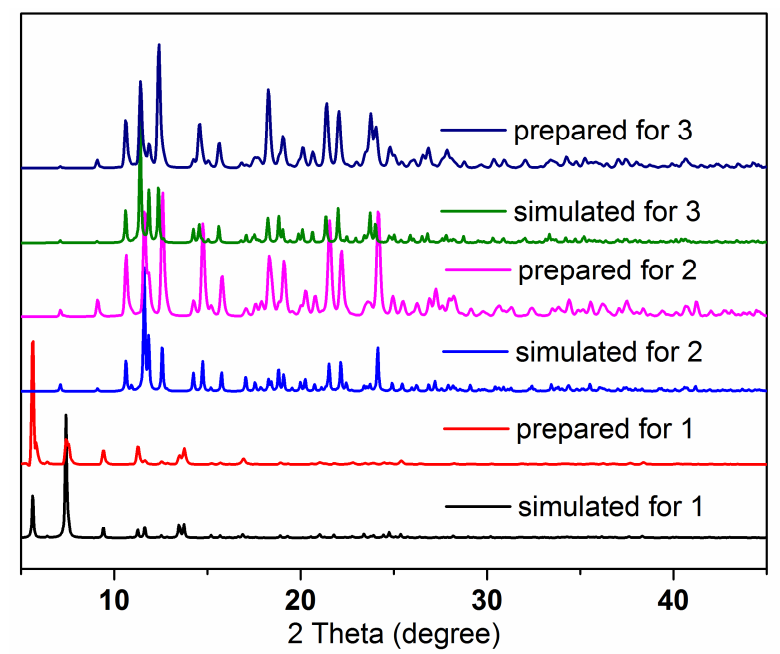

Figure 4. PXRD curves for 1-3. 


\subsection{In Vitro Cytotoxicity Study against the Cancer Cells}

In order to preliminarily evaluate the anticancer efficacies of the three complexes (1-3), their tumor cell growth inhibition activity was assessed in vitro against four human liver cancer cells (HepG2, Bel-7402, SMMC7721, and MHCC97) by MTT assay with the cisplatin drug as the refer. Expose time was set to $48 \mathrm{~h}$ and the cell growth inhibition activity effects of cisplatin were used to make a comparison with the results of $\mathbf{1}-\mathbf{3}$. DMSO was used to dissolve the compounds at the concentration of $1 \mu \mathrm{M}$, and the diluted solution was added into the cell culture.

The data, which represent means \pm SEM of three independent tests carried out in duplicate, are plotted in Figure 5a. A descending order could be observed for the anti-proliferative activity of the test complexes toward each type of the tumor cell lines used, which might be ascribed to the measured concentration required to inhibit tumor cell proliferation by $50 \%\left(\mathrm{IC}_{50} \mu \mathrm{g} / \mathrm{mL}\right)$. From the results above, we can conclude that the new compounds 1-3 demonstrate comparable growth inhibition activity toward all four types of cancer cells $\left(\mathrm{IC}_{50}=34-56 \mu \mathrm{g} / \mathrm{mL}\right)$ with the reference drug.
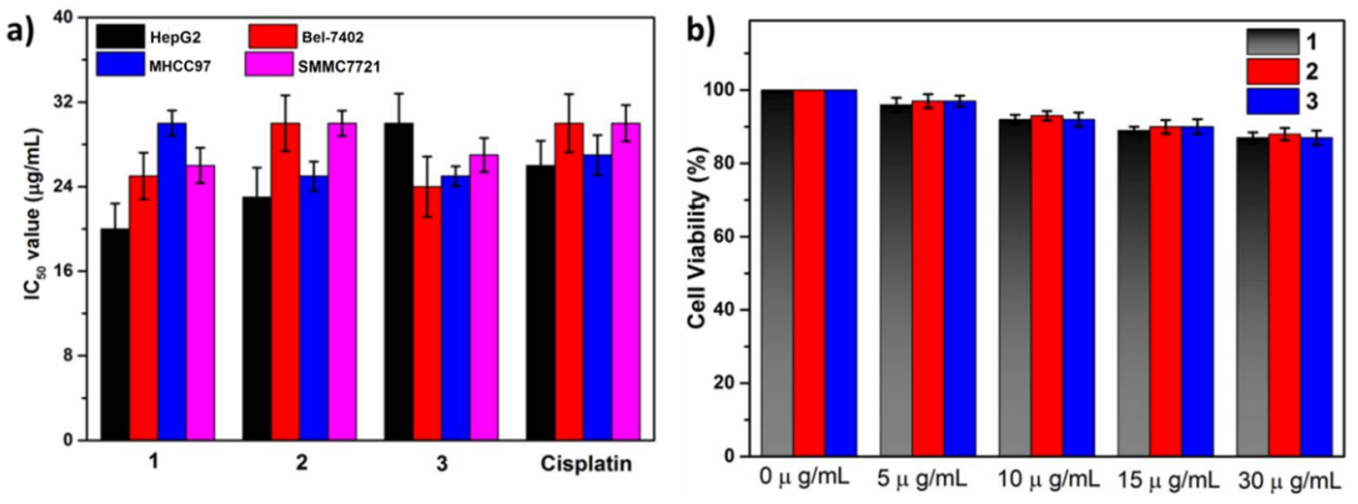

Figure 5. (a) Growth inhibitory effects of 1-3 and cisplatin against HepG2, Bel-7402, SMMC7721, and MHCC97 cells; and (b) cell viabilities of the human oral epidermal cells after incubation with 1-3 at different concentrations for $24 \mathrm{~h}$.

To probe the cytotoxicity of the as-prepared three compounds toward the human normal cells in vitro, oral epidermal cells (human normal cells) were selected to incubate with 1-3 for $24 \mathrm{~h}$ under different concentrations $(0-30 \mu \mathrm{g} / \mathrm{mL})$. Figure $5 \mathrm{~b}$ shows the cell viabilities of the three complexes, which are all above $84 \%$ even at a concentration of $30 \mu \mathrm{g} / \mathrm{mL}$. The above experimental results indicate that the three complexes showed low cytotoxicity toward the human normal cells.

\section{Conclusions}

The X-ray single crystal study demonstrates reveals that the metal-organic complex $\mathbf{1}$ is a trinuclear cluster that consists of two (pzTp) $\mathrm{Fe}(\mathrm{CN})_{3}$ units and one $\mathrm{MnMe}_{4} \mathrm{TACD}$ unit that connected by the $\mathrm{CN}$ ions, while compounds 2 and 3 are isostructural and demonstrate 1D chain-like structure that formed by the connection of the (pzTp) $\mathrm{Fe}(\mathrm{CN})_{3}$ units and the $1 \mathrm{D} \mathrm{M}(\mathrm{II})$-chains though the $\mathrm{CN}$ ions. Furthermore, the in vitro cytotoxicity of compounds 1-3 was studied against four human liver cancer cells (HepG2, Bel-7402, SMMC7721, and MHCC97) via the 3-(4,5-dimethylthiazol-2-yl)-2,5-diphenyl tetrazolium (MTT) assay experiments, which reveals their potential use as anticancer drugs.

Author Contributions: B.-H.S. conceived and designed the experiments; X.D. performed the experiments; C.L. analyzed the data; G.-F.A. contributed reagents/materials/analysis tools; B.-H.S. wrote the paper.

Acknowledgments: This work was supported by grants from the Natural Science Foundation of Inner Mongolia (2017MS(LH)0819).

Conflicts of Interest: The authors declare no conflict of interest. 


\section{References}

1. Lian, X.; Huang, Y.; Zhu, Y.; Fang, Y.; Zhao, R.; Joseph, E.; Li, J.; Pellois, J.P.; Zhou, H.C. Enzyme-MOF Nanoreactor Activates Nontoxic Paracetamol for Cancer Therapy. Angew. Chem. 2018, 4, 845-856.

2. Qiao, X.; Su, B.; Liu, C.; Song, Q.; Luo, D.; Mo, G.; Wang, T. Selective Surface Enhanced Raman Scattering for Quantitative Detection of Lung Cancer Biomarkers in Superparticle@MOF Structure. Adv. Mater. 2018, 30, 1702275. [CrossRef] [PubMed]

3. Zhou, J.; Tian, G.; Zeng, L.; Song, X.; Bian, X. Nanoscaled Metal-Organic Frameworks for Biosensing, Imaging, and Cancer Therapy. Adv. Healthc. Mater. 2018, 30, 1800022. [CrossRef] [PubMed]

4. Choi, G.; Kim, T.H.; Oh, J.M.; Choy, J.H. Emerging Nanomaterials with Advanced Drug Delivery Functions; Focused on Methotrexate Delivery. Coord. Chem. Rev. 2018, 359, 32-51. [CrossRef]

5. Pal, A.; Lin, J.B.; Chand, S.; Das, M.C. A 3D Microporous MOF with Mab Topology for Selective $\mathrm{CO}_{2}$ Adsorption and Separation. ChemistrySelect 2018, 3, 917-921. [CrossRef]

6. Kaur, R.; Chhibber, M.; Mahata, P.; Mittal, S.K. Induction of Catalytic Activity in ZnO Loaded Cobalt Based MOF for the Reduction of Nitroarenes. ChemistrySelect 2018, 3, 3417-3425. [CrossRef]

7. Sotnik, S.A.; Polunin, R.A.; Kiskin, M.A.; Kirillov, A.M.; Dorofeeva, V.N.; Gavrilenko, K.S.; Eremenko, I.L.; Novotortsev, V.M.; Kolotilov, S.V. Heterometallic Coordination Polymers Assembled from Trigonal Trinuclear $\mathrm{Fe}_{2}$ Ni-Pivalate Blocks and Polypyridine Spacers: Topological Diversity, Sorption, and Catalytic Properties. Inorg. Chem. 2015, 54, 5169-5181. [CrossRef] [PubMed]

8. Gupta, S.; Kirillova, M.V.; da Silva, M.F.C.G.; Pombeiro, A.J.L.; Kirillov, A.M. Alkali Metal Directed Assembly of Heterometallic Vv /M (M = Na, K, Cs) Coordination Polymers: Structures, Topological Analysis, and Oxidation Catalytic Properties. Inorg. Chem. 2013, 52, 8601-8611. [CrossRef] [PubMed]

9. Gu, J.Z.; Kirillov, A.M.; Wu, J.; Lv, D.Y.; Tang, Y.; Wu, J.C. Synthesis, Structural Versatility, Luminescent and Magnetic Properties of a Series of Coordination Polymers Constructed from Biphenyl-2,4,4'-Tricarboxylate and Different N-Donor Ligands. CrystEngComm 2013, 15, 10287-10303. [CrossRef]

10. Dias, S.S.P.; Kirillova, M.V.; André, V.; Kłak, J.; Kirillov, A.M. New Tetracopper(II) Cubane Cores Driven by a Diamino Alcohol: Self-Assembly Synthesis, Structural and Topological Features, and Magnetic and Catalytic Oxidation Properties. Inorg. Chem. 2015, 54, 5204-5212. [CrossRef] [PubMed]

11. Singha, D.K.; Majee, P.; Mondal, S.K.; Mahata, P. A Luminescent Cadmium Based MOF as Selective and Sensitive Iodide Sensor in Aqueous Medium. J. Photochem. Photobiol. A Chem. 2018, 356, 389-396. [CrossRef]

12. Wei, L.Q.; Li, Y.; Mao, L.Y.; Chen, Q.; Lin, N. A Series of Porous Metal-organic Frameworks with Hendecahedron Cage: Structural Variation and Drug Slow Release Properties. J. Solid State Chem. 2018, 257, 58-63. [CrossRef]

13. Hynek, J.; Brázda, P.; Rohlíček, J.; Londesborough, M.G.S.; Demel, J. Phosphinic Acid Based Linkers: Building Blocks in Metal-Organic Framework Chemistry. Angew. Chem. 2018, 130, 5110-5113. [CrossRef]

14. Zhao, L.; Zhang, Y.J.; Hu, J.X.; Jiao, C.Q.; Wang, J.L.; Duan, C.Y.; Liu, T. Coexistence of the Single Chain Magnet and Spin-Glass Behavior in a Cyano-Bridged $\left\{\mathrm{Fe}^{\mathrm{III}}{ }_{2} \mathrm{Fe}^{\mathrm{II}}\right\}$ Chain. Inorg. Chem. Commun. 2016, 66, 55-58. [CrossRef]

15. Hoshino, N.; Iijima, F.; Newton, G.N.; Yoshida, N.; Shiga, T.; Nojiri, H.; Nakao, A.; Kumai, R.; Murakami, Y.; Oshio, H. Three-Way Switching in a Cyanide-Bridged [CoFe] Chain. Nat. Chem. 2012, 4, 921-926. [CrossRef] [PubMed]

(C) 2018 by the authors. Licensee MDPI, Basel, Switzerland. This article is an open access article distributed under the terms and conditions of the Creative Commons Attribution (CC BY) license (http://creativecommons.org/licenses/by/4.0/). 